\title{
Baile para matar saudades- reflexões sobre o uso do vídeo numa experiência de recriação musical
}

DoI

http://dx.doi.org/10.11606/ 2179-0892.ra.2018.145520

\section{Erica Giesbrecht}

- Universidade de São Paulo / São Paulo, São Paulo, Brasil

$\boldsymbol{\nabla}$ egiesbrecht@gmail.com

RESUMO

Dentre os temas veementes nos debates etnomusicológicos contemporâneos, as relações entre música e memória, em especial as recriações musicais, têm propiciado um terreno fértil para reflexões. É nesse campo de discussões que se insere este artigo, que parte de uma recriação musical produzida em esforço conjunto entre pesquisadora e sujeitos etnográficos para elaborar algumas reflexões. Refiro-me ao Baile para Matar Saudades, uma festa dançante realizada em Campinas, em 2014, com o objetivo de reproduzir os bailes negros dos anos 1950 no interior de São Paulo. Lançando mão das imagens desse evento, de sua preparação e de outros fazeres musicais de meus interlocutores no presente, realizei um longa metragem homônimo, como forma de disseminação da pesquisa. Na etnomusicologia, assim como na antropologia, a questão das formas de representação e expressão nativa levantam desafios, por se tratar também um campo de natureza etnográfica. O desenvolvimento desses assuntos pela antropologia visual serve de igual forma às etnografias interessadas nas interações humanas mediadas pela música, por razões que vão desde as possibilidades extratextuais de expressão da dança e da música até o diálogo etnográfico e a representatividade dos sujeitos em campo. O escopo último deste artigo, portanto, é discutir os papéis da realização fílmica numa pesquisa interessada na emersão de memórias através da recriação musical.
PALAVRAS-CHAVE

Memória, corpo, música, dança, comunidade negra, bailes negros, Campinas 
O "espelho em movimento".

"A memória é uma ilha de edição" - Waly Salomão

"Olha aí, meu Deus! Pô eu tô elegante, hein meu! Nem eu sabia disso, que eu tava com essa bola! Nossa Senhora..." Admirado ao ver sua própria imagem num notebook, seu Aluízio Jeremias encerra com essa frase o documentário Baile para matar saudades, resultante de uma experiência de diálogo entre a etnomusicologia e a antropologia visual da qual foi um dos protagonistas. Na filmagem que o surpreende está cantando "Aquarela do Brasil" à frente da Orquestra Leopoldo de Tupã, uma tradicional e renomada orquestra de bailes atuante desde os anos 1930 no interior de São Paulo'. É o centro das atenções num baile de gala realizado em 2014 com a intenção de reproduzir eventos similares ocorridos nos anos 1950. Está vestindo seu terno azul marinho e chama a atenção dos presentes pelas evocações de sua performance: sua voz, sua postura e a expressão de seu rosto trazem a grandiosidade dos cantores daquela época. Como escreveu Priscila Ermel,

"O vídeo, como o espel ho, reflete inúmeras possibilidades de construções e representações de si e do outro, trabalhando a consciência da autoimagem numa perspectiva que envolve os tempos presente, futuro e passado" (2009: 162).

Já afetado pela experiência do baile e agora atravessado pelas sensações que as imagens daquele evento lhe provocavam, seu Aluízio me dizia que poucas coisas mais o emocionavam na vida. Aos 74 anos, já havia sido presidente de uma das escolas de samba mais importantes de sua cidade natal, Campinas, e já alcançara reconhecimento por sua obra como artista plástico. No entanto, reviver a experiência de um baile de gala, como não se via na cidade há mais de cinquenta anos, o fizera estremecer. Seu Aluízio ensaiara semanas a fio para cantar com a orquestra que fazia parte das lembranças douradas de sua mocidade. Ao ver sua própria imagem refletida no "espelho em movimento" (2009:161), como colocou Ermel, me descreveu seu estado no momento da performance "Eu me senti o dono do mundo!"

Os bailes que frequentou quando jovem uniram sua história de vida à de um grupo social que há muito se reconhece como "comunidade negra" em Campinas. Aluízio, juntamente com outras quatro pessoas, Rosária Antônia, José Antônio, Carlos Augusto Ribeiro e Leonice Sampaio, todos negros e com idades entre 70 e 90 anos, foram os principais interlocutores de minha pesquisa de pós-doutorado, inserida no projeto temático "A experiência do Filme na Antropologia", desenvolvido pelo Grupo de Antropologia Visual (GRAVI) do Departamento de Antropolo-

1 Fonte: http://www. leopoldoeorquestratupa. com.br/Historia.html. Acesso em 31 de maio de 2015. 
gia da Universidade de São Paulo². A proposta do projeto era, através de uma narrativa audiovisual de suas histórias de vida, compreender como aqueles bailes haviam contribuído para com a formação e continuidade dessa comunidade.

Aluízio Jeremias e Carlos Augusto Ribeiro - o "Tio Dudu”, como é chamado pela Comunidade Jongo Dito Ribeiro da qual hoje é integrante - envolveram-se com o mundo do samba ${ }^{3}$ desde muito jovens. Seu Aluízio se encantara ainda na infância o carnaval e, na década de 1970, fundou a escola de samba Rosas de Prata $^{4}$. Foi ele o compositor de vários sambas-enredo que renderam prêmios a essa escola. Também dono de um notável talento para as artes plásticas, sempre se encarregou dos designs dos carros alegóricos e figurinos das escolas de samba de que fez parte desde a adolescência ${ }^{5}$, além de destacar-se como artista plástico, com exposições periódicas pela cidade. Tio Dudu também se envolveu com grupos de samba desde muito jovem. Foi criador da escola de samba Lords da Prainha, hoje não mais existente, e também compositor de alguns sambas. Paralelamente, ambos eram sócios de clubes culturais negros na cidade, tendo vivenciado importantes episódios de suas vidas naquelas festas.

Já Leonice Sampaio - hoje mais conhecida como "Tia Nice do Acarajé" por vender os quitutes baianos mais famosos de Campinas - era uma forte presença nos bailes negros da cidade. Isso se devia ao seu envolvimento com a organização de vários daqueles eventos e sua notável participação no movimento social negro - foi diretora do Clube Machadinho ${ }^{6}$ e fundadora do Museu do Negro ${ }^{7}$, dentre outras atividades de liderança que evidenciam sua força politica. Bastante requisitada era também sua prima, Rosaria Antônia - chamada hoje de "Sinhá" pelos colegas do grupo Urucungos - pela graça de sua dança e por suas diversas candidaturas aos concursos de "Rainha do Baile", que a tornavam uma espécie de "garota propaganda" daqueles eventos.

Finalmente seu José Antônio, irmão mais velho de Sinhá falecido em 2016, dedicou-se desde sua mocidade como instrumentista na única banda de retreta negra de Campinas, a Corporação Musical dos Homens de Cor. Esta banda foi criada em 1933 como resposta à restrição do ingresso de negros em bandas musicais brancas. Em suas primeiras décadas de existência, foi uma das poucas fontes de ensino musical para negros em Campinas. Da Banda dos Homens de Cor, como é mais conhecida, saíram muitos músicos negros que, mais tarde, foram compor grandes orquestras de bailes do estado de São Paulo. Ademais, a própria corporação musical promovia bailes em sua sede.

No momento em que realizava minha pesquisa, essas pessoas faziam parte de grupos culturais negros que, através da recriação de repertórios tradicionais de música e dança ${ }^{8}$, vêm promovendo um vigoroso movimento de visibilização das culturas de matriz africana em Campinas. Suas atuações em atividades culturais promovidas por negros, no entanto, se iniciaram ainda em sua mocidade. Ao lon-
2 O projeto temático "A experiência do filme na antropologia" se desenvolveu entre entre 2010 e 2015 com apoio da FAPESP

3 A relação entre e comunidade negra não está sendo tratada aqui como imanente. Mesmo porque havia escolas de samba frequentada por brancos a exemplo da "Camisa Verde" à época. Entretanto, as escolas de samba pelas quais passaram seu Aluízio e tio Dudu não só eram majoritariamente negras, como também realizavam seus ensaio em bairros habitados quase exclusivamente por famílias negras.

4 "A GCRES Rosa de Prata é uma escola de samba de Campinas, estado de São Paulo. Foi fundada em 1975 na Vila Castelo Branco, por Aluízio Jeremias. Em 2010 a Rosa foi campeã do carnaval da cidade". Extraído de Artigo na Wikipédia (27/04/2016). https://pt.wikipedia.org/ wiki/Rosa_de_Prata

$5 \quad$ Inclui-se aí a Estrela D’alva, fundada em junho de 1950. Sediada hoje na Vila Costa e Silva, a escola teve seu início no bairro Taquaral. Sob as cores azul e branco e simbolizada por uma estrela, a escola foi presidida por "Beiçola" até 1978, período em que recebeu vários títulos do carnaval campineiro. Entre seus membros mais famosos, está o sambista Nenê do Cavaco.

6 Mais detalhes nas próximas páginas.

7 O Museu do Negro foi fundado em 2002 em uma casa no bairro do Cambuí doada por seu proprietário, Adão Bernardino dos Santos. Santos 
go de suas vidas, se envolveram em uma diversidade de práticas de dança e musica que integravam os negros e também tornavam suas práticas culturais notórias no cenário da cidade. Dentre todas elas, bailes ocupavam posição de destaque. Organizados entre negros como resposta à negação de seu ingresso em bailes de brancos, reuniam centenas de frequentadores assíduos, mobilizando e conectando boa parte dos habitantes negros da Campinas dos anos 1940 aos 1960.

Intensos, densos, ora carismáticos, ora coléricos, os cinco desvendaram esse universo às câmeras, atentas à sua expressividade. Os equipamentos registraram performances, bem como seus sentimentos sobre seu fazer musical atual, além de incitar reflexões sobre como estas práticas os levaram a desenvolver sensibilidades e transformaram suas percepções de si mesmos, como negros e como velhos no mundo.

Porém, suas memórias constituíam um desafio à parte. Levando em conta as considerações de Maurice Halbwachs (1968), para quem a manifestação de memórias individuais é uma consequência de sua inserção em campos de significados de domínio coletivo, percebemos que aquelas eram memórias de todo um grupo social ao qual se sentiam pertinentes. Além disso, o uso da câmera permitia acesso a níveis ainda mais profundos da memória, que extrapolavam o conteúdo semântico das narrativas. Refiro-me ao que Paul Connerton chamou de "memórias habituais" (1990: 107), noção que nos permite compreender como, em seus modos de falar, andar, cantar, tocar instrumentos, dançar, dentre uma série de outros hábitos, há um compêndio de memórias corporizadas de toda uma coletividade.

Mas como seria possível perscrutar e exprimir aquele conjunto de memórias incorporadas que se revelava diante das câmeras? Como compreender códigos elaborados a partir das experiências de convívio da comunidade negra através daqueles corpos e suas performances? E ainda, como analisar o papel articulador das práticas musicais do passado agora que os bailes glamourosos já não aconteciam mais?

Em meio ao percurso etnográfico, surgiu a possibilidade de recriação e filmagem daqueles eventos musicais. Na literatura etnomusicológica, experiências de recriação musical têm provocado intenso debate por mobilizarem fortemente dimensões emocionais humanas, levarem à expressão de saberes incorporados, evocarem diferentes interesses relacionados ao passado e moldarem a consciência histórica de diversos grupos sociais (Shelemey, 2006; Bithel, 2006; Reily, 2006). Deste modo, a possibilidade de reprodução de um baile de gala negro seduzia pelo potencial de acionar poderosos mecanismos de memória. Inspirada em relatos sobre eventos transcorridos entre os anos 1940 e 1960, tal recriação foi de fato crucial, não apenas para a produção do filme, mas também para provocá-los e despertar suas memórias para um diálogo etnográfico. era um cocheiro negro, que a construíra o imóvel entre 1911 e 1913, para ser residência de sua família. A casa abrigava também carros e animais de transporte, sendo um dos imóveis mais antigos do bairro. No início do século XX, o bairro do Cambuí, hoje uma das áreas mais nobres de Campinas, abrigou uma comunidade de negros e imigrantes italianos em meio às chácaras e casarões dos comerciantes e barões do café. Encerrando suas atividades em 2006, 0 museu continuou de forma itinerante, sob a direção do jornalista José Luís de Oliveira, mais conhecido como Zélus.

8 A ideia da (re) tradicionalização defendida por Teixeira, Garcia e Gusmão (2004) serve de base para minha compreensão desse movimento. Partindo de situações nas quais, a exemplo do que acontece em Campinas, instauram-se processos de recuperação e revalorização daquilo que se considera tradicional, os autores compreendem que a (re) tradicionalização é um processo através do qual grupos sociais resignificam práticas culturais que consideram tradicionais, a partir de intenções e interesses no presente, sem que isso desemboque necessariamente em busca pela autenticidade ou "raízes", por um lado, e nem em deturpação ou dervirtualização dessas tradições por outro. 
Incorporando a câmera como meio de reflexão e expressão etnográfica, a pesquisa explorou os modos pelos quais o filme é capaz de potencializar e até mesmo transformar a experiência de recriação musical, para além de meramente registrá-la. A elaboração fílmica, todavia, iniciou-se bem antes da realização do baile em si, passando pelas filmagens dos preparativos e das expectativas que esse processo despertava, além de entrevistas e encenações especificamente voltadas à emersão das memórias de meus interlocutores.

Neste artigo, examino as potencialidades da associação entre a câmera e a recriação musical como meios de investigação. Discuto como a reprodução do baile, associada à produção do filme, foram críticas para a pesquisa, tanto por seus produtos quanto por seus processos. $\mathrm{O}$ vídeo, para além de meio de registro e observação, foi um instrumento de comunicação, provocação e proposição, como já sugeriu a filmografia de Jean Rouch na década de 1970. Tão importantes quanto o baile e o filme foram os processos relativos a suas preparações acionando sensibilidades, evocando memórias e produzindo a expressão de hábitos incorporados entre meus interlocutores de experiência etnográfica.

\section{BAILES E A “COMUNIDADE NEGRA" EM CAMPINAS}

Em 2011 eu encerrava minha pesquisa de doutorado junto a grupos campineiros dedicados à performance de repertórios tradicionais de dança e música de matriz africana, como o Urucungos, Puítas e Quijêngues ${ }^{9}$, a Casa de Cultura Tainãº, o Jongo Dito Ribeiro", dentre outros. A visibilidade desses grupos em Campinas se deve, ademais da vivacidade de sua sonoridade, cores e movimentos, à participação de homens e mulheres idosos. Respeitados e bastante considerados pelos membros mais jovens de suas comunidades musicais, estes senhores e senhoras chamam a atenção dos expectadores e, não raro, direcionam as sensibilidades de todos os presentes nas apresentações para as dimensões ancestrais do repertório musical que executam. Carregando memórias das formas de convivialidade entre os negros da cidade de outros tempos, acabaram se tornando o foco principal de minha pesquisa de pós-doutorado.

Para compreender as experiências de vida de meus interlocutores, é necessário antes esclarecer a imbricada relação entre música, memória e comunidade que envolve suas vidas. Durante a pesquisa, em vários momentos faziam referência à "comunidade negra", da qual se sentiam parte. Este é um termo êmico recorrentemente utilizado na rede de pessoas com que se relacionam, sejam eles jovens ou idosos, homens ou mulheres, vivos ou mortos, declarando-se negros ou brancos. Apesar de hoje essa comunidade estar espalhada pelos bairros de Campinas devido ao processo de urbanização, seus membros constantemente reelaboram sentidos e valores que geram e regeneram sentimentos de per-
9 Ogrupo Urucungos surgiu a partir de uma oficina de repertórios de matriz africana ministrada pela folclorista Raquel Trindade ao final da década de 1980 , na Universidade Estadual de Campinas. Até hoje ensaiam e apresentam o repertório ensinado durante o curso: basicamente esquetes de manifestações culturais propriamente ditas - como jongos, lundus, samba lenço, samba de roda, maracatu, coco, cirandas, dentre outras estilizadas na década de 1940 pelo pai de Raquel, o poeta Solano Trindade, gerando pequenas coreografias cênicas desses legados de matriz africana. Com o passar dos anos incorporaram outra tradição musical, o samba de bumbo, tido como a expressão negra mais importante do interior estado de São Paulo, não apenas durante o período de escravidão, mas até as primeiras décadas do século XX.

10 Criada em 1989, a Casa de Cultura Tainã foi o único centro cultural profícuo dentre vários criados pela prefeitura de Campinas na mesma época, mais tarde extintos por falta de subsídios. Apoiando-se principalmente nos ganhos adquiridos através de sua Orquestra de Tambores de Aço, a Casa Tainã sobreviveu e se tornou um centro comunitário de referência da cultura negra em Campinas, dispondo hoje de uma arrojada estrutura disponibilizada à comunidade, que inclui biblioteca, laboratório de computadores, espaços para lazer e estúdio de som.

11 Como o próprio nome dessa comunidade já diz, "Jongo Dito Ribeiro", toda sua atividade musical está centrada na pratica do jongo. 
tença. Atualmente, fazer parte dessa comunidade significa associar-se a uma ou mais organizações sociais (casas de cultura, organizações não governamentais, entidades educacionais, grupos culturais, religiosos, políticos, dentre outras) e estar presente em eventos públicos, (festas, reuniões religiosas, apresentações culturais, atos políticos) que mantém essa rede de pessoas conectada, sabendo uns dos outros, conhecendo-se e reconhecendo-se.

A música é constantemente lançada como forma de integração nesses eventos públicos. As performances de grupos culturais como Urucungos, Casa Tainã ou Dito Ribeiro sempre envolvem seus espectadores em suas danças e músicas, tornando-os parte do espetáculo - durante a Lavagem das Escadarias da Catedral' ${ }^{12}$, por exemplo, as comunidades religiosas participantes cantam seus pontos repetidas vezes como meio de inserção daqueles que vão se juntando ao seu cortejo ou cerimônia através do canto coletivo e shows de rodas de samba ou RAP, estilos musicais que frequentemente inserem seus públicos em suas performances, são geralmente parte das programações festivas promovidas pela comunidade. Revela-se, deste modo, uma sociabilidade musicalmente mediada, que pode ser compreendida através concepções mais amplas do fazer musical, como a ideia de musiking, desenvolvida por Christopher Small (1998). O "musicar"13 pode ser qualquer forma de engajamento com música. Para além da performance musical em si, ouvir música, falar sobre música, participar ou organizar eventos musicais são formas de "musicar". Tais práticas integram pessoas num universo musical, engajando-as num processo interativo ligado à produção e vivência da música.

A participação nessa comunidade é facultativa e demarca um investimento identitário de pertencimento ao grupo. É claro que há muitas pessoas em Campinas que se reconhecem como negras. Isso, no entanto, não as torna membros da comunidade, sendo para tanto imprescindível o engajamento nas formas de socialização já mencionadas. Some-se a isso ainda o fato de não ser preciso ser negro para se fazer parte dessa rede de sociabilidade, que abarca uma diversidade de fenótipos e identidades. No passado, porém, a criação de associações negras de naturezas diversas era o único modo de se garantir socialização, acolhimento e proteção diante de um contexto no qual a discriminação racial subjazia às práticas sociais.

Ao final da escravidão nas lavouras de café, a maior parte da população negra de Campinas deslocou-se das senzalas para o centro, em sua maioria formando cortiços - foram poucas as famílias que permaneceram nas áreas rurais. Como nos conta Maria Lúcia Ricci (2003), a partir década de 1950, como parte de uma política de urbanização da cidade, os habitantes dos cortiços foram remanejados para bairros então considerados periféricos e sem infraestrutura, como Ponte Preta, Vila Marieta, Vila Costa e Silva, Vila Rica e São Bernardo, dentre
Alguns dos formadores desse grupo tiveram passagem pelo Urucungos e pela Casa Tainã, acumulando experiências e aprendizados. Hoje, a comunidade jongueira gere um centro cultural, a Fazenda Roseira, na qual, além de jongo, muitas outras atividades culturais acontecem, todas ligadas a legados culturais de matriz africana.

12 Esse evento começou a ser articulada por duas mães de santo da cidade, Mãe Corajacy e Mãe Dango, com o objetivo de levar o candomblé para a rua, como é feito em Salvador, na Lavagem do Bonfim. Um ato de preconceito ao candomblé, cometido contra mãe Dango, teria impulsionado a iniciativa em 1985. Na época, ela cumpria obrigações do candomblé e trabalhava como varredora de rua. Por baixo do uniforme laranja de gari, vestia roupas brancas, mijeloguns (fios de contas) no pescoço e na cabeça careca o ojá (lenço branco) por baixo do chapéu. Segundo ela mesma relata, em certo dia daquele ano foi agredida física e verbalmente com palavras como "bruxa" e "feiticeira" por um homem, enquanto varria o Largo da Catedral. A humilhação foi revertida em grande mobilização entre terreiros de candomblé e umbanda de Campinas, que a partir do ano seguinte começaram a se reunir para lavar as escadarias todas as manhãs de Sábados de Aleluia, após uma difícil reunião com Dom Gilberto Pereira Lopes, bispo da Arquidiocese de Campinas. Até hoje, as portas da Catedral Metropolitana de Campinas se mantêm fechadas. As autoridades da Igreja Católica local se posicionam com respeito e não interferem. 
outros. Descritas por Ricci como "espaços negros", foi nestas vizinhanças que famílias negras perfizeram laços de socialização que enfim recriaram o senso comunitário das senzalas e cortiços de outrora.

As fundações das primeiras associações civis negras, que procuravam reestabelecer a integração entre essas pessoas, datam dos tempos iniciais da vida urbana, a exemplo da Liga Humanitária dos Homens de Cor (1915), uma espécie de serviço social que mantinha sedes em várias cidades do Brasil, e da própria Banda dos Homens de Cor, criada em 1933. Tais associações foram criadas devido à restrição do ingresso da população negra nas existentes instituições destinadas a brancos. Nas narrativas de meus colocutores, são recorrentes lembranças de proibições de sua entrada em espaços privados brancos, ou prescrições de lugares destinados a eles em recintos públicos, veículos coletivos, praças e ruas ${ }^{14}$.

A obra de Lenita Nogueira (2001) nos mostra que, tal como no presente, num passado que remonta à Campinas escravocrata, a sociabilidade negra também era mediada por eventos musicais que nutriam sentimentos de pertença a uma comunidade. Após a abolição e nas décadas que se seguiram, sambas de bumbo e formações carnavalescas continuaram a agregar a população negra de cidades paulistas, como descrevem Marcelo Manzzati (2005) e Olga von Simson (2007). A partir dos anos 1940, quando parte de meus interlocutores já vivenciava sua mocidade, outro tipo de evento passaria a atrair a atenção da população jovem: os bailes dançantes promovidos por clubes negros.

Até meados da década de 1970, três clubes comporiam o agitado cenário cultural dos negros de Campinas: o Clube Machadinho, O Clube Nove de Julho e o Elo Clube. Tais associações visavam atender a uma demanda de lazer da população negra, respondendo ao mesmo tempo à inadmissão nos espaços brancos. Assim, eram oferecidos desde atividades esportivas até festas, shows e, principalmente, bailes.

Dentre os três, o mais requintado era o Elo Clube, lembrado por meus interlocutores pelo rigor exigido nos trajes, pelas regras de etiqueta e pelas orquestras que contratavam para animar seus bailes. No entanto, a aura de elegância e respeito era mantida em todos os clubes, dos bailes mais simples aos mais glamourosos. Juntos, esses três clubes ofereciam uma agenda semanal de bailes que se podia frequentar do final da tarde (matinês), até o fim da noite (soirées), aos finais de semana. Os valores dos ingressos também variavam. Se por um lado isso permitia o acesso dos jovens menos abastados aos clubes mais baratos, por outro, contribuía para a elitização do grupo de pessoas que tinha condições de frequentar os bailes mais caros e requintados.

Em um nível ainda mais faustoso, os memoráveis bailes de gala aconteciam em Campinas em ocasiões mais raras, não mais do que três vezes ao ano ${ }^{15}$. Estes grandes bailes comportavam entre quinhentas e mil pessoas, exigindo muito
O evento, que faz parte do calendário oficial cultural de Campinas desde 1997.

13 Ver Projeto Temático FAPESP "O musicar local, novas trilhas para a etnomusicologia" vigente entre 2016-2020, coordenação Suzel Reily.

14 Ver também Lapa (1995), Maciel (1997), Nogueira (2010), Von Simson (2005).

15 Bailes de gala também eram realizados em outras cidades do interior de São Paulo, como Araraquara, Jundiaí, Rio Claro, formando uma agenda anual de eventos que interligava pessoas por todo o estado (Tenório, 2007; Giesbrecht, 2011). 
mais espaço do que os tradicionais clubes negros dispunham. Deste modo, eram organizados em outros espaços, maiores e mais luxuosos: os mais requintados clubes "brancos", tais como o Clube Regatas, o Tênis Clube, o Clube Cultura e a Fonte São Paulo. Em geral eram produzidos pelos conhecidos "Lord" Constancinho e "Lord" Carabina, também envolvidos com outras atividades culturais ou esportivas na cidade ${ }^{16}$. Para estes bailes, eram contratadas somente as melhores orquestras do estado de São Paulo - entre as campineiras a Orquestra de Birico, a Orquestra Som de Cristal, a Orquestra Columbia e a Orquestra Itamaraty; e entre as de outras cidades paulistas, Leopoldo e Orquestra Tupã, Arley e sua Orquestra, Orquestra Sul América de Jaboticabal, Julinho e sua Orquestra, dentre outras.

Valquíria Tenório (2007), mostra que dezenas de bailes negros no estado de São Paulo faziam parte de uma vasta agenda de eventos anuais. Em seu estudo, percebeu que tais bailes eram poderosos eventos sociais que acionavam encontros de amigos, parentes e conhecidos, numa experiência marcada pela apropriação do chamado "glamour negro"17 e por negociações de status e poder. Ou como bem coloca Aluízio Jeremias logo no início do filme, "Esses bailes ...era pra dar um pouco de autoestima pra comunidade negra".

Eventos musicais complexos, pela demanda de organização e por concentrarem milhares de pessoas, os bailes propiciavam um elo entre mundos musicais negros que não se comunicavam, tão diferentes entre si quanto escolas de samba e bandas de retreta, sociabilizando uma grande rede de pessoas e seus "musicares". Como mostra "Baile para matar saudades", a trajetória de seu José evidencia a relação entre bailes e bandas de música, uma vez que a formação de músicos negros foi decisiva para a continuidade das orquestras. Paralelamente, o filme mostra que havia uma ligação entre os clubes negros, escolas de samba e demais formações carnavalescas, através de figuras como Lord Carabina, diretor do Clube Nove de Julho e presidente da escola de samba Princesa D'Oeste, e de tantas outras.

Em um contexto diferente - as atividades musicais de migrantes mineiros no $A B C$ paulista em torno das folias de reis - Suzel Reily (2002) percebeu exigências de treino, engajamento e continuidade dos participantes, aplicando a noção de "comunidades de prática" (Lave e Wenger, 1998) para desenvolver sua análise ${ }^{18}$. Para além do envolvimento afetivo possibilitado por ensaios, encontros, procissões ou jornadas, havia uma demanda de trabalho em conjunto para que se chegasse a um resultado musical final, unificando-se neste processo motivações, afetos e expectativas, bem como os diversos conhecimentos derivados daquela prática musical.

Reily mostra como o aprendizado vai além do repertório, estendendo-se para negociações entre os participantes sobre como melhor executar as tarefas que os unem. Neste sentido, muito mais do que competência técnica, faz-se
16 Lord Carabina também era presidente da Escola de Samba Princesa D'Oeste; Lord Constancinho era produtor de outros bailes de elite, como "Rainha da Primavera" e "Garotas Campineiras".

17 Termo cunhado por jornais como "Clarim d'Alvorada", "Progresso", "Voz da Raça", dentre outros que compunham a imprensa negra da época (Bastide, 1951)

18 Em síntese, para Lave e Wenger (1998) comunidades de prática são formadas por pessoas que se comprometem em um processo coletivo de aprendizado sobre domínio qualquer; compartilham interesse ou paixão por algo que fazem e aprendem ou aprimoram seus conhecimentos à medida que se relacionam com regularidade. Aprender pode ser tanto a razão pela qual a comunidade se junta, quanto uma consequência incidental da interação dos envolvidos. A construção de um repertório compartilhado de recursos, como experiências, histórias, ferramentas ou maneiras de abordar problemas recorrentes, exige tempo e interação continuada. A associação, portanto, implica num comprometimento com esse domínio e assim, uma competência compartilhada que distingue os membros de determinada comunidade de outras pessoas, resultando em identidades de grupo. Tais identidades emergem, dentre outros aspectos, do aprendizado em coletividade que transforma a vida dos participantes, recriando suas histórias pessoais. 
necessário um saber global, que relacione todos os aspectos associados à atividade, incluindo a ciência de comportamentos apropriados, o reconhecimento das hierarquias, a aceitação de responsabilidades e o treino de sensibilidades. Investimentos de tempo, dinheiro, disposição e seus retornos são elementos que proporcionam prazer e certamente reforçam o sentimento de pertença a uma comunidade de prática musical.

Em Campinas, cada um dos grupos reunidos por sambas, bandas, orquestras, agremiações carnavalescas e, sobretudo, por bailes negros pode ser visto uma "comunidade de prática musical", como sugeriu Reily"19. Todos envolviam centenas de pessoas com objetivos comuns e agindo em cooperação para o alcance de um resultado musical desejado, ao mesmo tempo em que propiciavam produção e troca de conhecimentos diversos, especialmente sobre as formas de sobrevivência frente à segregação, à violência e ao racismo ${ }^{20}$. Todos esses eventos exigiam planejamento ou longos períodos de ensaio. Longos e trabalhosos, esses processos demandavam convivência e constantes negociações, além de envolverem seus participantes emocionalmente. Os produtos finais, por sua vez - as rodas de samba, a música de baile, as marchinhas de carnaval - produziam sensibilidades estéticas e simbólicas compartilhadas, acionando inúmeros sentimentos e reflexões sobre a música que se estava ouvindo ou dançando. Some-se a isso o fato dessas comunidades estarem em constante fluxo de ideias, informações, pessoas e relações, formando o que Wenger e Lave definiriam como "constelação de comunidades" (1998: 67), ou seja, a interligação entre vários núcleos formando uma teia ampla e coesa de sociabilidades.

Ademais de reunirem pessoas envolvidas em diferentes universos sonoros, bailes eram ao mesmo tempo ofertados em abundância e segregados dos espaços brancos, características que operaram significativamente para o desenvolvimento e coesão da rede social negra em Campinas. Sempre era possível frequentar algum baile, ou dançar em um baile mais caro vez ou outra. Assim, as mesmas pessoas conviveram basicamente nos mesmos lugares e circuitos, o que rendeu de casamentos a formações de movimentos políticos (Tenório, 2007; Felipe, 2013).

Aqueles eventos musicais não contribuíram apenas para formação de uma comunidade negra coesa e resistente às sucessivas dispersões urbanas, mas também solidificaram bases para que gerações futuras dessem continuidade a um senso de pertencimento, envolvendo os descendentes diretos das antigas famílias negras e pessoas advindas dos contínuos fluxos migratórios a partir dos anos 1950 (Ricci, 2003). Como mostra o documentário, laços de solidariedade se solidificaram tendo os bailes como espaço de mediação. Subversivamente, a resposta à segregação, que poderia ter sido a dispersão e enfraquecimento daquelas pessoas, foi a própria comunidade.

Nas memórias dos anciãos negros que se dispuseram a colaborar com a pes-
19 Ver Giesbrecht e Souza (2013: 6)

20 Ver aprofundamentos sobre esta questão em Ciesbrecht (2011) 
quisa residiam, portanto, pistas importantes para a compreensão da formação da rede de sociabilidade negra campineira que, nutrida por práticas coletivas de música e dança, continuou até os dias de hoje. Tão desafiante quanto sua elicitação era expressá-las, tornando-se atraentes as possibilidades oferecidas pelo vídeo para a realização deste trabalho etnográfico.

\section{FILMANDO MEMÓRIAS: ESCOLHAS, DISPOSITIVOS E CONSTRUÇÕES DE LINGUAGEM}

Quando se iniciaram as filmagens, minha relação de convivência com meus colaboradores já beirava uma década. A convivialidade iniciada ainda durante minha pesquisa de doutorado acabou moldando nossas relações. Como membros mais velhos de suas comunidades musicais, sempre demostraram acolhimento e zelo pelos participantes mais jovens. Assim, contei privilegiadamente com uma relação de generosidade e disponibilidade desde que lhes propus uma pesquisa mediada pelas câmeras.

A proposta era simples: além de filmar suas performances nos grupos em que atuam hoje, na medida em que estivessem disponíveis, eu os levaria para passear pela cidade; visitaríamos seus lugares de memória: praças, ruas, antigas moradias, igrejas, cemitérios, mercados, escolas de samba, clubes, etc. Assim, poderíamos conversar sobre as coisas que haviam marcado suas vidas. Nossos equipamentos eram igualmente simples: munidos de uma única câmera filmadora, um tripé, um monopé, um microfone de lapela, um gravador Zoom e por vezes algum equipamento de iluminação, íamos eu e mais um cinegrafista ao encontro de meus interlocutores. Nossa reduzida equipe procurava dividir funções: filmagem e monitoramento de som a cargo do cinegrafista; interação, translado de carro, direção geral, roteiro de entrevistas, escolhas de situações a serem filmadas sob minha responsabilidade. Praticamente todas as filmagens foram realizadas individualmente, apesar de nosso esforço em tentar juntar os cinco participantes da pesquisa.

Não me surpreendeu o fato dos itinerários urbanos escolhidos por cada um dos cinco serem musicais: a igreja de São Benedito, diante da qual seu José Antônio tocava em procissões com Banda dos Homens de Cor no passado, e que agora é o local onde tio Dudu dança jongo com a Comunidade Dito Ribeiro²1; o gentrificado bairro do Cambuí, hoje considerado área nobre da cidade, que abrigava antigamente o cortiço "Porteira Preta", onde Aluízio Jeremias ouvia seu pai tocando nas rodas de samba; o prédio onde antigamente funcionava a rádio CPR 9 na qual Sinhá e tia Nice não podiam entrar por serem negras e que agora é templo da Igreja Universal; as antigas sedes de clubes negros, onde todos já haviam dançado inúmeros bailes, agora transformados em estacionamentos, lojas de pneus, com exceção única do Clube Cultural Machadinho. Esses pas-
21 Anualmente a Comunidade Jongo Dito Ribeiro realiza uma roda de jongo no dia Consciência Negra (20 de novembro) no Largo da Mãe Preta, situado em frente à Paróquia de São Benedito em Campinas. O lugar é simbólico para a comunidade negra de Campinas uma vez que São Benedito é tido como santos protetores dos negros no Brasil desde o período de escravidão. Esta igreja, em especial, teve sua construção iniciada em 1839 por iniciativa de Mestre Tito, um africano escravizado. Além disso, no Largo da Mãe Preta está um monumento de nome homônimo, inaugurado em 1984 após um esforço conjunto entre o movimento negro e da comunidade religiosa ligada à paróquia. 
seios, junto com as entrevistas, eram frequentemente estimulados por músicas, fotografias, recortes de jornais antigos, dentre outros objetos de memória. Assim, foram levantadas lembranças e reflexões profundas sobre envel hecimento, o modo como o preconceito racial havia se transformado ao longo dos anos, as mudanças ocorridas na cidade e seus modos de serem negros nela.

As filmagens criavam o ensejo para que falassem de si mesmos, por vezes reiterando suas facetas mais conhecidas, outras vezes mostrando seus lados desconhecidos. Nunca demonstraram timidez ou receio diante das câmeras; ao contrário, permitiram-se até mesmo se emocionar, carregados por suas lembranças. Os depoimentos eram ora direcionados à sociedade campineira, ora à comunidade negra, ora a seus amigos e parentes, ora a mim - "pesquisadora", "jornalista", "branca"-, ora a mim - pessoa próxima, à quem queriam se revelar. Em muitos momentos a presença das câmeras mais parecia uma desculpa para que nos conhecêssemos melhor. Tendo como interlocutora uma pessoa em média quarenta anos mais jovem, preocupavam-se em situar pormenorizadamente suas lembranças. Para falar sobre uma canção, era preciso dizer quem era o artista, de onde vinha, em que rádio a canção tocava, em que rua ficava o prédio da rádio, o que existe lá agora. Longas, suas narrativas pareciam mergulhá-los na Campinas de sua mocidade com seus sons, cores, espaços e pessoas. Este salto no tempo pôde ser captado pelas câmeras, materializando-se em seus olhares, sorrisos, lágrimas, pausas, no ritmo de sua respiração afetada pela recordação.

O processo de filmagem não foi simples. Em alguns casos nossas sessões eram canceladas por motivos de saúde; em outros, porque haviam sido convidados para alguma apresentação de última hora. Tia Nice e seu Zé já tinham problemas de saúde que limitavam sua mobilidade, praticamente não podendo ser filmados fora de casa. Outro desafio foi a edição, realizada em sua maior parte com recursos técnicos e humanos do Laboratório de Som Imagem e Antropologia da Universidade de São Paulo ${ }^{22}$. Se por um lado o tempo de filmagem aprofundara meu conhecimento de suas personalidades e histórias, por outro expressar a complexidade dessas vidas exigiu esforço e criatividade.

Cada corte parecia adulterar suas narrativas, alongadas pelos muitos anos de vida. Sentia, além disso, que alguns personagens pareciam muito mais "fortes" do que outros. Como equilibrá-los, construindo uma narrativa fílmica interessante? Como retratá-los chamando atenção para as adversidades de suas vidas e para a beleza musicalmente expressiva com que reinventaram seus mundos? Como apresentar as múltiplas camadas de suas memórias através de imagens? Se a escrita etnográfica nos propicia um certo controle sobre a apresentação de nossos interlocutores, permitindo-nos elaborar a descrição da porção de suas vidas que nos deram a conhecer, as filmagens nem sempre contribuem do mesmo modo: muitas vezes as imagens nos faltam, ou nos escapam! Apresentar os

22 No processo de edição contei com a preciosa colaboração de Ricardo Dionísio, um dos técnicos do Laboratóro de Imagem, Som e Antropologia. 
sujeitos de uma etnografia através do filme torna-se um grande desafio porque nosso material não são nossas memórias ou notas de campo, mas aquilo que conseguimos filmar.

Baptiste Buob (2016) descreve exatamente meu estado no momento da edição: "Para um etnólogo, com raras exceções, a primeira experiência fílmica é sinônimo de frustração. Ao voltar de seu local de investigação, mobiliza um conjunto comum de justificativas (deficiências e questões técnicas, questões éticas, o medo de "perturbar", falta de competência, falta de estrutura definida, etc.) para explicar que não tem material para "fazer um filme". Após muito refletir, comecei a vislumbrar um formato de filme que os mostrasse separadamente ${ }^{23}$. Se o objetivo era dar ênfase à musicalidade envolvida em suas trajetórias e às suas memórias, sem abandonar a relação que criávamos durante a pesquisa, era preciso montar capítulos individuais.

As sessões de Sinhá, Tio Dudu e seu Aluízio foram as primeiras a serem montadas, por serem eles personagens aparentemente mais "fáceis". As tomadas de Sinhá, por exemplo, estão repletas de cenas de dança, com o grupo Urucungos, e de reflexões sobre sua performance. Com muita naturalidade, nos conta como dançar repertórios de matriz africana a fizera reconstruir-se como mulher, negra e agora, idosa. No seu corpo, inteiramente entregue à dança, histórias de s, sambas de bbumbo e bailes suntuosos são narradas a cada rodopio, a cada requebrado, das pontinhas de seus pés até os dedos das mãos estendidos. Tão leve e cativante quanto sua dança é sua relação com seu jardim, que acolhe as câmeras com imensa beleza, ainda que contido em dezenas de latinhas e embalagens de plástico espalhadas sobre dureza de um chão de concreto. Sinhá altera o destino da argamassa e da sucata com a mesma beleza com a qual subverteu a rejeição no mercado de trabalho, por ser "muito preta". É sobretudo a leveza de seu corpo o que sustenta a doçura e a gentileza em seu dia a dia. O corpo, a dança e as flores de Sinhá respondem ao racismo com a leveza e a gentileza de outros tempos.

Tio Dudu, cujo bom humor marca as relações de sociabilidade pelos mundos musicais em que transita, exacerba esta característica diante das câmeras. Piadas, sorrisos, gargalhadas são constantes ao recobrar sua história, mesmo quando revela algum fato doloroso. A construção de sua parte no filme contou com imagens em que dança jongo com a Comunidade Dito Ribeiro, ou toca seu tamborim em seu grupo de pagode, o Casarão SP. Seu envolvimento com música marca os momentos mais importantes de sua vida: a lembrança do pai jongueiro e ferroviário, que lhe ajudara a arranjar o emprego de maquinista e que povoara sua infância e sua juventude com festas no terreiro; o sonho juvenil de ir morar no Rio de Janeiro para juntar-se à na marinha e conhecer as escolas de samba; o encontro com a moça que seria sua esposa por mais de cinquenta anos em um baile de gala.
23 A experiências da editora Carolina Gama foi crítica para a realização desse primeiro recorte do filme. 
Seu Aluízio compartilha com as câmeras dois tipos de performance: o canto e a pintura, talentos que empregou durante toda a vida no ambiente das escolas de samba. Sua voz passeia por sambas consagrados e pelos clássicos da era do rádio no Brasil. Suas mãos precisas revelam a comunidade reunida em torno dos sambas numa Campinas de outrora. Deixam entrever uma longa prática com pincel e tinta, iniciada nas travessuras com o carvão, na parede da casa em que viveu quando menino. Em suas reflexões sobre seus modos de expressão, as artes plásticas e a música parecem partes de uma coisa só. Misturam-se instintivamente nas práticas de alguém que cuidava desde a concepção dos carros alegóricos e fantasias até a composição de sambas-enredo. Seu Aluízio tinha uma mente inquieta, desconfiou do professor de história que, na sua adolescência, Ihe dissera que Zumbi dos Palmares havia se suicidado. Emociona-se ao lembrar de como sonhava em contar outra versão dessa história: criaria uma escola de samba e comporia um enredo, narrando a traição que sofrera o líder de Palmares. "E consegui! ", exclama entre lágrimas. A genialidade e o talento de seu Aluízio não respondem apenas ao racismo, mas revertem a maneira degradante através da qual somos socialmente educados a pensar sobre a trajetória dos negros no Brasil. Revela-se neste capítulo o modo pelo qual seus sambas-enredo ajudaram centenas de pessoas envolvidas na escola Rosas de Prata a incorporar uma memória vitoriosa, substituindo a narrativa degradante comumente disseminada.

Se com os três personagens citados até o momento foi possível transitar por lugares de memória e explorar suas práticas expressivas, juntamente com seus grupos culturais, com Tia Nice e seu José isso não era possível. Como então interagir com suas sensibilidades e suas próprias produções expressivas através do uso da câmera?

Quando se iniciaram as filmagens com seu José, já havia um ano que não frequentava os ensaios da Banda dos Homens de Cor. Devido a um problema de saúde, estava impossibilitado de sair de casa; soprar o instrumento se tornara um grande esforço. Mesmo assim, não foi difícil provocá-lo. Para tanto, contei com a ajuda da direção da banda, que me disponibilizou fotografias e partituras, além do próprio instrumento. A filmagem do encontro em que lhe trouxe esses objetos acabou se tornando crítica para o filme, por exprimir a natureza da relação que eu mantinha com ele e com os demais. Surpreso por ter-lhe trazido o sax-horn, não conseguiu resistir muito tempo sem tocá-lo. Embora eu não tivesse tomadas de sua interação com o grupo musical do qual fizera parte por quase setenta anos, tinha diante de mim a possibilidade de reter, com a câmera, detalhes de um saber incorporado ao longo de décadas, e que se substancializava agora no cuidado com que limpava o instrumento, segurava-o nas mãos, tocava. Bem mais íntima, a câmera enfatiza a expressão de seus olhos, o inchar de suas bochechas, a articulação de suas mãos e o brilho de sua pele confundindo-se 
com o brilho do instrumento.

As fotografias o convidavam a mergulhar no passado e recontar uma trajetória musical que se iniciara tocando com o pai e os irmãos nos bailes de roças ao redor de Campinas e culminara em sua carreira na Banda dos Homens de Cor. Refletindo sobre seu percurso, reconhece o de muitos outros músicos negros e contemporâneos a ele que tiveram na banda uma oportunidade única de aprendizado de música de tradição escrita. O sítio em que viveu até a juventude está presente em seu sotaque e na singeleza de seu sorriso. Mas a simplicidade não fazia dele um homem menos sagaz, especialmente quando respondia àqueles que, buscando inverter o jogo da opressão social, chamavam a banda de racista ou segregacionista por manter o nome "Homens de Cor".

Finalmente tia Nice, cujas memórias transitam por inúmeros locais na cidade, não precisou sair de casa para partilhar com as câmeras os passeios de sua mente. E nem da cadeira sobre a qual repousava o corpo pesado, mas surpreendentemente móvel. Sua performance, bem conhecida dentro e fora da comunidade negra campineira, reside em sua oralidade. Tia Nice coleciona em suas memórias estórias de negros libertos e escravos que teriam vivido em Campinas. Em cada uma delas há uma vitória, uma revanche, conquistada pela força do protagonista, muitas vezes acudido pela intervenção divina.

A revanche é também a resposta que sua própria história de vida deu ao racismo. Proibida de usufruir de uma bolsa de estudos na infância por ser negra, ela se formaria mais tarde pelo SENAI como tecelã industrial e não poderia ser barrada em nenhuma empresa por lei. Percebendo-se como a única negra em seu local de trabalho, lançava mão da certeza de sua empregabilidade para "abrir caminhos": pedia demissão e procurava emprego em uma nova tecelagem a cada dois ou três anos, criando o ensejo para que outras negras fossem empregadas em seguida. As narrativas de tia Nice estão principalmente nos vigorosos desenhos que seus braços formam no ar, na sua língua afiada, no penetrante timbre de sua voz, na energia dos movimentos do seu corpo, no modo como arregala os ol hos tomada pela força de suas palavras. Suas memórias estão também no modo de preparar seu acarajé e em tudo o que seu olfato, seu tato e seu paladar sabem, sensibilidades que buscamos expressar através de sons e imagens.

Uma vez montados seus capítulos individuais, colocava-se um dos maiores problemas da fase de edição. Era necessário demonstrar de que modo os bailes de sua mocidade haviam entrecruzado suas trajetórias. Mas deixar suas narrativas sobre os bailes, bem como as filmagens da reprodução do evento e impacto deste em suas vidas apenas para o fim significava deixar para os últimos minutos de filme a própria experiência de recriação musical, tema central não só do documentário como também da própria pesquisa! A solução estética e narrativa encontrada foi iniciar o filme com fotografias dos bailes que haviam frequenta- 
$\mathrm{do}^{24}$, ao som de suas narrativas sobre aquelas festas, embaladas por um mambo tranquilo, convidando à dança a dois ${ }^{25}$. Este mesmo mambo passou a encerrar cada capítulo individual, encadeando cenas alternadas de suas atuações musicais no presente (ex. Sinhá dançando maracatu com o Grupo Urucungos; tio Dudu tocando pagode com o grupo Casarão SP) com cenas em que se vestiam elegantemente, como se estivessem se preparando para ir a um baile de gala. Dosadas em breves aparições, as memórias dos bailes vão construindo, ao longo do filme, uma narrativa subjacente que emerge finalmente nos derradeiros vinte minutos, conectando os fragmentos anteriormente apresentados. A trilha musical, o mesmo mambo dançante, é essencial para a construção fílmica, reaparecendo nessa sessão conclusiva do documentário e compondo, juntamente com cenas em que falam de suas memórias dos bailes, um ethos profundamente nostálgico. As cenas finais mostram nossos esforços, meu e de meus interlocutores, para reproduzir a festa, culminando no grande baile realizado em abril de 2014.

\section{UM BAILE PARA MATAR SAUDADES...}

Dito Ribeiro, ele, nas festas juninas dançava jongo, erguia mastro, convidava os amigos...Eu não participava muito, porque eu saía, né?...não ficava ali firme, que nem agora que eu sou o mais velho daqui do Jongo. Mas naquele tempo eu era rapaz...solteiro. la ter a festa lá, tavam preparando tudo, eu ia pra outros lados... Carlos Augusto Ribeiro.

É assim que Carlos Augusto Ribeiro, Tio Dudu, se recorda de seu pai, Dito Ribeiro, a quem a Comunidade Jongo Dito Ribeiro, da qual hoje é o membro mais velho, homenageia. Assim como Tio Dudu, muitos dos senhores e senhoras que atualmente participam do movimento cultural negro de Campinas têm fortes lembranças das festividades em torno do jongo, do samba de roda ou do samba de bumbo vivenciado pela geração de seus progenitores. Como já vimos, esses jovens de outrora tinham outros interesses, eram afetados por outras sonoridades e encontraram nos bailes a fórmula musical que os envolvia sensível e socialmente.

Percebendo a importância deste universo de sons, luzes, movimentos e elegância nas vidas de Sinhá, seu Zé, seu Aluízio, tio Dudu tia Nice e de toda sua geração, surgiu a ideia de recriação de um baile de gala aos moldes dos eventos do passado, inserindo-os numa experiência na qual suas memórias mais profundas pudessem vir à tona. Se rever fotografias dos antigos bailes causava-Ihes reações, o que a própria recriação de um baile, não poderia incitar?

A organização desse evento, ocorrido no dia 05 de abril de 2014, exigiu gran-
24 As fotografias de bailes da década de 1950 foram um ganho extraordinário para a pesquisa, proporcionado por Clória Bardi. Nascida em Muzambinho, em 1950, Glória se mudou para Campinas na infância. Foi funcionária da prefeitura, entre 1980 e 1984, e da Unicamp, entre 1984 e 2006. Os anos de trabalho nessas instituições, que concentram muitos funcionários negros, fortaleceram seus vínculos com a comunidade negra local. Glória não chegou a viver a época dos grandes bailes, mas encantou-se com o glamour presente nas fotografias com as quais tomou contato pela primeira vez em 2009. De lá para cá, vem utilizando uma estratégia muito simples: de posse de um volumoso álbum, vai a festas, eventos, ou mesmo ao centro da cidade e, quando encontra uma pessoa idosa $\mathrm{e}$ negra, seja ela conhecida ou não, o mostra. Ao ver as imagens de bailes negros do passado, seus interpelados são capazes de identificar nomes das pessoas fotografadas, lembramse dos eventos, dizem se estavam presentes e com quem estavam. E além de acionarem todas essas memórias, muitas vezes contribuem com a coleção, oferecendo-lhe outras fotografias que por ventura tenham. Assim que recebe novas fotografias, Clória as escaneia e em seguida as devolve a seus interlocutores. Assim, formou uma coleção valiosa de fotografias, que hoje beira 500 itens entre artigos de jornal, convites de eventos, além de outros documentos. Essa coleção tem circulado pela cidade em suas andanças. Foi assim que, de fato, muitas pessoas tiveram acesso a suas próprias imagens, que julgavam perdidas.

25 "Mariana", composição de Mauro Dárcio e Ewelter Rocha, responsáveis pela trilha musical original do documentário. 
de esforço, pois não havia recursos humanos ou financeiros disponíveis para sua realização. Em novembro de 2013, encaminhei um pedido de apoio à Secretaria de Cultura de Campinas que, aceitando a proposta, acabou se encarregando da contratação da Orquestra Leopoldo de Tupã e da concessão do salão de festas do Clube Campineiro de Regatas. Contando com este auxílio, comecei a divulgar a ideia entre os grupos culturais negros, o que se potencializou pela propagação entusiasmada de meus próprios interlocutores. Em pouco tempo, o Clube Cultural Machadinho aceitou se encarregar da cozinha e do bar. Assim, no início do ano de 2014, o evento já havia sido amplamente divulgado na comunidade e eu já contava com os pilares de uma festa de grande porte: a orquestra, o salão e o bar. Como chegou a me dizer um dos membros da diretoria do Clube Machadinho, já não havia mais como parar o baile.

Restavam ainda, no entanto, alguns gastos adicionais: seguranças, garçons, decoração do salão, dentre outros. Como contávamos com dinheiro público, não seria possível cobrar entrada, o que tornava necessário encontrar outra solução para cobrir aquelas despesas. Foi quando me arrisquei lançando uma campanha em vídeo para arrecadar recursos junto a um site de financiamento colaborativo, o Catars $e^{26}$. Para além da própria campanha, a elaboração deste teaser teria grande importância para a pesquisa e para a produção do filme. Pela primeira vez, os participantes se envolveriam com filmagens por meio de uma encenação, especificamente dirigida à angariação de fundos para a realização da festa. Além disso, seus depoimentos eram essenciais para que soubéssemos como eram aquelas celebrações; sem isto teria sido impossível recriá-las.

Impulsionados pela proposta que se abria, mesmo os mais descrentes, colaboraram generosamente, dispensando seu tempo, sua energia e sua disposição. Neste teaser, atuam como se estivessem se aprontando para um baile, em seguida compartilham memórias sobre as festas de sua mocidade e finalmente pedem a contribuição dos expectadores para o evento ${ }^{27}$.

Neste exercício de encenação, a câmera perfazia um dispositivo catalisador das elaborações de si mesmos que realizavam durante a performance, potencializando os desdobramentos da sua dramatização, como no filme "Pyramide Humaine" (1959), em que Rouch lança mão do sociodrama na interação com seus interlocutores. A encenação que os sujeitos de minha pesquisa fizeram, vestindo-se e arrumando-se como se estivessem se preparando para uma noite de gala, seguida de conversas sobre os grandiosos eventos de antigamente, incitou-os a reelaborar sentidos de referência a suas próprias memórias, desenvolvendo reflexões no momento da realização do vídeo.

À medida em que suas filmagens iam Ihes sendo mostradas - a campanha quando pronta, trechos de filmagens e fotografias do baile, após sua realização - um processo de mão dupla de intervenção fílmica entrava em curso, uma vez
26 Ver a campanha em: https://www.catarse.me/pt/ bailedasaudade?ref=profile_ created_projects

27 O vídeo pode ser encontrado em vimeo. com/86638015. Com quase 3.000 visualizações, mobilizou não apenas fundos, mas um grande número de pessoas interessadas, tornando o Baile para matar saudades um evento notório em Campinas. Os espectadores alcançados pelo teaser, contudo, foram os mais jovens, habituados ao uso das redes sociais e de sites de compartilhamento de vídeo como o YouTube. O público alvo do projeto - os antigos frequentadores dos bailes negros, em sua maioria com mais de setenta anos-ouviu a respeito do baile sobretudo através da rede de contatos pessoais acionada por meus interlocutores e seus amigos mais próximos. Comprometidos e afetados pelas expectativas geradas, espalharam a notícia e pediram doações, multiplicando anseios entre centenas de pessoas de sua geração. 
que suas reações ao se verem também estavam sendo filmadas. Novamente a exemplo dos procedimentos de Rouch, neste jogo de cena o filme operou simultaneamente como linguagem e como meio de pesquisa, produzindo formas alternativas de auto-representação. O recurso ao filme permitia-Ihes recriarem sua história, reforçando a possibilidade de narrarem suas experiências, para dentro e para fora dos limites da comunidade negra.

Se para os mais velhos a reconstituição do baile parecia um sonho, nem todas as lideranças do movimento negro atual apoiaram a ideia inicialmente. Para alguns, a ostentação das festas negras, décadas atrás, não passava de um espelhamento sobre um modelo branco. Copiar ou exagerar a estética dos eventos aos quais não tinham acesso seria um empecilho para a criação de uma identidade própria. Recebi propostas como inserir grupos de batuque ou samba de bumbo no meio do baile, ou realizar a festa nas dependências de alguma das casas de cultura negra da cidade, dentre outras possibilidades de aproximação da festa com as estéticas atualmente sustentadas pelo movimento negro.

Confusa, resolvi consultar os mais velhos, para quem na verdade a festa era dirigida. Admirados com tais reações, foram unânimes em afirmar que os tambores, os pés descalços e as saias de chita não cabiam naquele contexto. E não fazia sentido al gum realizar uma festa daquele porte em um lugar que não estivesse à altura de sua sumptuosidade. Para chamar a atenção da cidade, como conseguiam antigamente, o evento precisaria comportar centenas de pessoas e deveria ser realizado em um lugar elitista, especialmente um lugar onde a presença dos negros causasse choque.

Além disso, esta era uma oportunidade única de se mostrarem aos mais jovens de um modo ainda pouco conhecido; era preciso seguir à risca o modelo do passado para que tivessem noção do que haviam sido aquelas celebrações. Sua reação mostrava o quão multifacetada e ilimitada podem ser as expressões culturais negras, não sendo possível encerrá-las num único modelo. A geração mais velha dera ao racismo uma resposta elegante. Diante desta réplica, só me restou retornar as lideranças contrariadas pedindo que refletissem sobre que direito tínhamos, no presente, de negar aquelas memórias aos anciãos da comunidade negra. Mais tarde, no baile finalmente realizado em abril, pude confirmar a sensibilização que o processo todo provocara, com a presença e o apoio de várias lideranças dos grupos negros de Campinas.

Realizado em abril de 2014, o Baile para matar saudades, que mais tarde emprestou seu nome ao filme, reuniu mais de 500 pessoas e agradou tanto que provocou uma forte demanda para que fosse reeditado no ano seguinte ${ }^{28}$. Dispondo de uma equipe de fotógrafos, cinegrafistas e técnicos de som, foi possível captar a aura de elegância, a entrega total dos corpos à dança e à música,
28 A segunda edição do baile não contou com os mesmos apoios da primeira, tendo os ingressos de serem cobrados, portanto. Mesmo assim, um público de mais de 600 pessoas a prestigiou no Clube do Bomfim em 5 de abril de 2015. Neste segundo evento, apenas Sinhá, seu Aluízio e tio Dudu estavam presentes. Seu José e tia Nice estavam doentes. Antecedendo o baile, foi possível exibir uma versão preliminar do filme, o que rendeu novos desdobramentos para a pesquisa. 
os mais inesperados encontros e o profundo envolvimento emocional entre os participantes. Revelaram-se às câmeras memórias sociais incorporadas, trazidas à tona pela música e pela dança.

Cabe explicar o processo de incorporação de memórias pelo qual esses anciãos passaram aqui, e de que forma eventos musicais foram fundamentais para que se efetivasse. A noção de "incorporação" proposta por Thomas Csordas (1990) repensa a relação entre práticas corpóreas e esquemas culturais. Em sua construção teórica, Csordas encontra pontos de intersecção entre o entendimento da percepção em Merleau-Ponty (1999 [1962]) e da prática em Bourdieu (2003 [1970]). Para Csordas, o paradigma da incorporação estava enunciado tanto no paradoxo sujeito-objeto de Merleau-Ponty, quanto no de estrutura e prática de Pierre Bourdieu. Enquanto essas dualidades se colapsam para os dois autores, 0 corpo é a arena que as unifica, pois está entre o sujeito e o objeto e igualmente entre a estrutura e a prática. Uma vez estabelecido o ponto de intersecção entre os dois pensamentos, Csordas constitui sua tese da incorporação: o corpo é a um só tempo socialmente informado e pré-objetivo; é o reino das possibilidades espontâneas e inesperadas ao qual as práticas são objetivamente ajustadas e socialmente estruturadas. Assim, no lugar de um ente passivo aos esquemas de aculturação, o corpo é em si sujeito e unidade a partir da qual tanto a percepção quanto os esquemas da cultura são engendrados.

É esse corpo-sujeito que na abordagem de Paul Connerton (1999) abriga a "memória habitual" dos grupos sociais por meio de suas práticas. No pensamento de Connerton, os valores e verdades mais caros de um povo são tacitamente aceitos, compartilhados e, sobretudo, incorporados através do hábito, nem sempre sendo documentados oficialmente. Assim, Connerton se desloca do campo da memória social (Halbwachs, 1968) para a memória habitual, tomando por hábito um dispositivo que "transmite o sentido de operatividade de uma atividade continuamente praticada e também a realidade do exercício, o efeito consolidador dos atos que se repetem" (Connerton, 1999: 107).

A memória habitual pertence ao domínio das coisas banais, aquelas que não pensamos para fazer, ações mecanizadas do dia-a-dia como gesticulações, trejeitos, meneios, expressões do rosto, posturas do corpo. O modo como desempenhamos esse conjunto de ações media constantemente nossas relações com outros seres humanos; tais ações são resinificadas através de processos perceptivos altamente fluídos e independentes de nossas intenções ou controle sobre o que estamos fazendo. Esses hábitos são de suma importância para a memória coletiva de um grupo social, diz Connerton:

...todos os grupos confiam aos automatismos corporais os valores e as categorias que querem à viva força conservar. Eles saberão como o passado pode ser bem 
conservado na memória, por uma memória habitual sedimentada no corpo (Connerton, 1999: 117).

O autor considera as cerimônias, os rituais e as comemorações momentos privilegiados de revisitação da memória social incorporada nos hábitos. Tratam-se de situações em que os sentidos de todos os participantes estão envolvidos e coletivamente direcionados para o mesmo fim. Nem sempre verbalizados, rituais fazem uso de símbolos, sons e movimentos que estimulam nossos pontos de percepção; são momentos em que se pode experienciar e rememorar as regras tácitas que regem a cultura, por vias não necessariamente intelectuais. Articulando práticas que envolvem o corpo, as emoções e o drama coletivo, Connerton encontra nos rituais o momento máximo da expressão das memórias sociais incorporadas. Tratam-se de enunciações performativas nas quais é revisitado um conjunto de valores e de práticas de um grupo. Comemorações assumem, em última instância, o papel de via privilegiada da transmissão das memórias inerentes aos grupos sociais (1999: 43).

Olhar para os antigos bailes de gala negros sob a perspectiva das memórias habituais nos permite compreendê-los como instâncias de imersão coletiva na qual música e dança operavam como instrumentos viabilizadores da incorporação de valores caros à comunidade dançante envolvida. Em tempo, o pensamento de Csordas é crítico para o entendimento de que, longe de uma mera assimilação de códigos corpóreos seguidos em bailes brancos, bailes negros eram meios de incorporação de outros valores. Dentre eles o glamour negro, cunhado pela imprensa negra dos anos 1950 e frequentemente lembrado por meus interlocutores para expressar o orgulho e o empoderamento que a possibilidade de produzir festas tão ou mais opulentas que os bailes brancos Ihes conferia ${ }^{29}$. Esse glamour se expressava no requinte das posturas corporais, na exigência do brio no ambiente, no cavalheirismo da dança. Bailes negros eram ensaios de probidade e elegância através das práticas corporais. Aqueles corpos dançantes eram agentes produtores e transformadores naquele ambiente cultural, fazendo emergir potencialidades de transformação a partir de processos criativos de dança.

\section{O FILME NUMA PESQUISA ETNOMUSICOLÓGICA SOBRE MEMÓRIAS MUSICAIS}

A recriação do baile produziu um tipo de situação que a ação dos grupos culturais negros de Campinas já vinha produzindo há algumas décadas: a possibilidade de reexperimentação de expressões de música e dança não mais existentes. No caso dos grupos culturais, tais recriações vêm servindo à incorporação de uma memória ancestral, que remonta ao período de escravidão no Brasil e à qual se quer reapropriar por meio dos usos do corpo. Já a recriação do baile tinha 
a intenção de revolver memórias de situações musicais já experimentadas pelos participantes, ou seja, permitir que revivessem uma experiência musical buscando com isso fazer emergirem suas memórias afetivas ${ }^{30}$.

Com suas particularidades, os dois tipos de recriação produziram efeitos análogos a outras experiências documentadas pela literatura etnomusicológica. O trabalho de Shelemay (2006), mostra que desde as entrevistas etnográficas é possível explorar lembranças musicais. O modo pelo qual a música entra em discussão durante uma entrevista oferece um bom exemplo de como memórias individuais são marcadas e transformadas em narrativas históricas coletivas em momentos de rememoração. Música, no pensamento de Shelemay, perfaz um mecanismo profundo e potente de retorno ao passado por envolver dimensões emocionais. Mais do que o conteúdo em si, comentários feitos em entrevistas, "revelam a maneira pela qual a experiência musical é sustentada pela memória, tanto como um mundo sonoro quanto como uma reflexão emocionalmente carregada sobre o passado" (Shelemay, 2006: 30).

Alinhando-se às reflexões de Shelemay, Caroline Bithel (2006), mostra como isto se torna ainda mais intenso quando a música em questão passa por uma suspensão, seja pelo esquecimento, pela morte daqueles que a praticavam, ou pela proibição de ser ouvida. Em sua etnografia, Bithel vascul ha as diferentes motivações, metodologias e ideologias de grupos envolvidos em recriações musicais chegando a diferentes abordagens e aos subsequentes usos do material levantado que, por fim, revelam atitudes e interesses diversificados em relação ao passado.

Celebrações, por sua vez, sustentam e reconstroem a consciência histórica através da envoltura do corpo e suas potencialidades sensíveis, como examina Reily (2006), alinhando-se diretamente a Connerton. Rituais, defende, permitem que os participantes reexperenciem e reincorporem suas visões de passado e, a partir disso, realizem projeções para o futuro. Reily também descreve as fortes ligações emocionais que muitas das pessoas em seu estudo têm em relação a repertórios e práticas que se perpetuaram no tempo, enfatizando o papel crítico desenvolvido pela experiência da performance para modelar a consciência histórica.

A reação de meus interlocutores ao ouvirem a orquestra tocando In the Mood de Glenn Miller, ou ao dançarem ao som de Besame Mucho, confirma o poder das recriações de celebrações musicais discutidas nos estudos citados. A especificidade do Baile para matar saudades, no entanto, reside no fato de ter sido, além de uma recriação musical, uma experiência fílmica. Dentre as novas questões trazidas pela intervenção da câmera na etnografia das memórias musicais daquelas pessoas, reside uma tecnologia de identificação. Não apenas deliciavam-se com o mundo sônico de seus anos dourados, como também reinventavam suas identidades, conscientes de que suas imagens e sons alcançariam outros públicos, talvez mais jovens, talvez participantes da comunidade negra, talvez não.
30 Lembrando, a recriação de jongos ou sambas de bumbo, dentre outros repertórios praticados pelos grupos culturais campineiros possuem efetivamente uma relação com a experiência de vida de seus participantes mais velhos, uma vez que muitos deles foram expostos a essas práticas na infância ou juventude. Ainda que não tomassem diretamente parte nestas práticas, estavam imersos nestes ambientes de corporalidades e hábitos que, mais tarde, quando da fundação dos grupos do presente, foram emanadas por seus corpos, transmitindo a seus companheiros mais jovens narrativas não verbalizadas de um passado ancestral (Falcão, 2006; Csordas, 1990). 
Possivelmente pela primeira vez em décadas, assumiam uma identidade glamourosa, até mesmo em choque com a estética do movimento cultural negro de que fazem parte no presente-choque este que não os impede de serem admirados e respeitados por seus companheiros mais jovens. "As mulher de hoje não sabe ser chique", dizia tia Nice, quando Ihe propus a ideia do baile. "Tem que ser uma orquestra", "todo mundo vestido com traje a rigor", recomendou fortemente tio Dudu quando enquanto filmávamos sua parte na campanha. A câmera tornava possível pormenorizar as especificidades de um evento musical ainda desconhecido dos mais jovens. Era necessário mostrar-lhes que, no passado, uma das respostas musicais ao racismo e à segregação era se revestir de elegância. "Os brancos pagavam pra ver os negros dançar", dizia orgulhosa tia Nice, ao se referir ao Baile da Pérola negra de 1957 no já demolido Theatro Municipal de Campinas - certamente o baile negro mais importante retido em suas memórias.

Como colocam Hikiji, Ferraz e Cunha,

Rever esses percursos nos faz pensar na produção audiovisual como agenciadora de diferentes formas de reflexividade e de expressão crítica. Os sujeitos que lidam com a invisibilidade derivada do não reconhecimento de seus modos de expressão podem, ao se apropriar de estratégias de produção de imagem, projetar para um contexto mais amplo suas formas de ver, seus pontos de vista, suas demandase críticas. As performances para a câmera são também exercícios de reflexão sobre as possibilidades de elaborar suas autoimagens e identidades (2007: 295).

A identidade glamourosa de que se apropriavam com a realização do baile potencializava-se por meio do filme, bem como as formas de reação ao racismo que haviam marcado sua geração, invisíveis dentro do movimento negro atual. Se, enquanto processo, a recriação do baile contribuiu para a emergências de subjetividades adormecidas em suas memórias, o filme criava o ensejo para novas enunciações de si mesmos.

Enunciações mais subjetivas se expressam também durante as filmagens de reações aos dispositivos empregados na pesquisa para provocar memórias. Nas entrevistas em que falávamos sobre música e sobre eventos musicais do passado, assim como na experiência provocada por Shelemay (2006), campos emocionais eram sensibilizados tracionando experiências, pessoas e lugares para o presente, através de fios condutores sonoros. Mas há aqui uma diferença crítica em relação às etnografias estritamente escritas. Numa experiência audiovisual, os interlocutores percebem que suas filmagens têm possibilidades quase ilimitadas de alcance de público e que coisas caras, embrionadas em suas experiências pessoais, estarão sujeitas às mais inesperadas plateias e interpre- 
tações (Banks e Morphy, 1997). As cenas em que seu Aluízio canta Castigo, ou em que tia Nice entoa Mãe Preta, evidenciam o quanto aspectos emotivos de suas memórias gravitam em torno da música que, embrenhada de sentido, serve como instrumento para falarem de $\mathrm{si}^{31}$. Como os demais, se revelavam diante da câmera, expondo momentos de profunda intimidade de suas trajetórias pessoais, delicadamente guardados em suas memórias por invólucros sônicos.

Canções, por sua vez, potencializadas por modos de interpretação específicos, têm a capacidade de provocar diálogos intersubjetivos, convidando os espectadores a entrar neste mundo interior de quem está sendo filmado. Se os aspectos exclusivamente sonoros da canção podem incitar nos ouvintes rememorações coletivas como a época, as pessoas, os lugares, para além de memórias subjetivas, as imagens de alguém cantando são carregadas de outros catalizadores de sensibilidade, possibilitando outras formas de apreensão de experiência. Mesmo os timbres de suas vozes decantam significados retidos em anos de existência humana (Zumthor, 1993). Os corpos dos entrevistados comunicam diretamente aos de seus espectadores, com as expressões dos olhos, das mãos, os tremores do maxilar, pausas, tiques. O mesmo ocorre enquanto dançam. Mais especialmente nos casos de Sinhá, seu Aluízio e tio Dudu, a dança perfaz um elo entre passado e presente, conectando seus corpos a comunidades de ambos os tempos. Imersas em passos de dança de salão, mas também das recriações de jongos e maracatus, suas corporeidades reúnem temporalidades atuais e ancestrais, comunicando-se com audiências das mais variadas gerações. Como escreveu MacDougall, a potencialidade do vídeo reside em sua capacidade de proporcionar uma comunicação corporizada entre as pessoas filmadas e quem filma e entre as pessoas filmadas e seus expectadores (2009:63). Este diálogo sensível comunica e produz referências de significado, para além dos próprios conteúdos da canção, tornando o santuário de memórias inscritas no corpo de cada um sensibilizantes a públicos de qualquer geração.

Entretanto, os dispositivos fílmicos não são neutros, mas mediam essas comunicações. Como demonstrou Carlos Sautchuck (2012), o filme, enquanto meio etnográfico, constrói-se como processo de interação; imagens são processo, muito mais do que produto. O que o autor conclui a partir de sua etnografia visual entre pescadores, se aplica diretamente à minha pesquisa. Existem conexões entre gestos de filmagem e a movimentação dos corpos das pessoas filmadas. O manuseio da câmera é também um processo de transformação técnica do próprio etnógrafo que, por intermédio do aparelho, se engaja numa relação substancialmente diferente com as atividades estudadas.

Para expressar as memórias incorporadas por meus interlocutores, através de sua música, sua dança, sua oralidade, era preciso acompanhar suas movimentações e atentar a seus ritmos. Os planos americanos adotados nas entrevistas, ou
31 Neste caso, música também poderia ser compreendida como uma "tecnologia de si", no sentido proposto por Foucault (1990). 
os planos abertos mostrando seus contextos de dança, mesclam-se a detalhes das mãos, pés olhos, enquadram gestos corriqueiros. Como falar de tio Dudu sem enquadrar os momentos em que tira o chapéu em reverência à dama com quem iniciará uma dança, seja num salão de baile ou numa roda de jongo? Ou como descrever a experiência de seu Aluízio como carnavalesco, sem filmar-lhe os pés dançando "miudinho", quando faz suas demonstrações como "baliza" ${ }^{2} \mathrm{de}$ escola de samba, ou ao cantar "Aquarela do Brasil, com a orquestra Leopoldo de Tupã? São essas frações de segundo captadas pela câmera que descrevem hábitos adquiridos por seus corpos nos diversos ambientes musicais existentes na comunidade negra, e que os moldaram como pessoas ao longo dos anos. Deste modo, a câmera não se pretende ausente para uma suposta aproximação entre espectador e objeto. Antes é admitida no filme, materializar-se no fluxo das ações guiada pelos movimentos e expressões daqueles que filma.

Do mesmo modo, a câmera também criou possibilidades de vislumbre de suas memórias. Sinhá e tio Dudu integram comunidades musicais que investem na recriação de sonoridades tradicionais de matriz africana, como jongos e sambas de bumbo. As filmagens de suas atividades nestes ambientes renderam imagens preciosas para ilustrar momentos retidos nas memórias deles e dos demais, referentes a seus próprios passados ou a um passado ancestral. Tomadas dos pés das dançarinas do Urucungos, durante uma apresentação no terreiro da Casa de Cultura Tainã, foram utilizadas como cutaways $^{33}$ da cena em que seu Zé se lembra dos bailes na roça que frequentava na juventude, por exemplo. Tomando a liberdade de emprega-las como o que MacDougall (1992) chamou de "sinais externos da memória", o filme constrói uma ponte entre o passado e o presente, que nada mais é do que uma representação imagética da conexão que suas histórias de vida fazem entre essas duas temporalidades.

Finalmente, a recriação de um evento musical do passado, quando filmada desde sua concepção até o resultado final, quebra protocolos estabelecidos por um "cinema-verdade", admitindo possibilidades de intervenção etnográfica e aproximando-se de uma abordagem orientada pela etno-ficção, remetendo-nos mais uma vez ao cinema de Jean Rouch. Além disso, as filmagens são capazes de narrar e exprimir expectativas, moções, encantamentos, fruições, dentre tantos outros processos, que muitas vezes passam ao largo das etnografias musicais escritas. A expressão dessas reações torna possível um outro nível de reflexão sobre o envolvimento humano nas recriações musicais, permitindo, ao mesmo tempo, uma aproximação intensa entre pesquisador e seus interlocutores, espectadores e pessoas filmadas.

A intenção do uso do vídeo nesta pesquisa foi lançar mão deste recurso técnico para um mergulho num universo sobretudo sensório. A câmera ao mesmo tempo interage e mostra seres humanos talhados pela vida e refinados pelos
32 Balizas seriam os precursores dos mestres-salas nos carnavais de São Paulo. Ele executava malabarismos com um bastão e abria caminho para a agremiação carnavalesca, ao mesmo tempo em que defendia o estandarte do grupo.

33 Recurso através do qual a cena principal é entrecortada por takes diferenciados, geralmente relacionados à cena principal (detalhes em zoom, cenas ilustrativas), com o objetivo de tornar a exibição mais dinâmica para o expectador. 
anos imersos em música. Faz escolhas, a partir de um repertório de memórias, e busca provocar os sentidos de quem assiste. Insiste nos pés moldados pelo tempo, que já pisaram em asfalto e em terra, correram, caminharam, dançaram descalços ou apertados em sapatos finos arrastando-se pelos salões. Procura o tempo todo pelas mãos calejadas pelas habilidades de dedilhar cordas, pistões, bater em peles de tambor, engomar saiotes e cozinhar. Interessa-se pela generosidade dessas mãos que hoje ainda seguram outras, mais jovens e incertas sobre a vida. Enquadra sorrisos, nos olhos e nos lábios das pessoas com quem interage. Escolhe o corpo e suas expressividades para contar histórias da comunidade negra de outrora, dos s nos becos aos bailes de glamour. Designa esse corpo para interagir e narrar memorias musicais. $\mathrm{O}$ vídeo prima por expressar o modo como a corporeidade de cada um dos personagens de "Baile para matar saudades carrega em si memórias de uma comunidade inteira, incorporadas e expressas no meio sônico, como proposição de um diálogo sensível entre sujeitos, etnógrafa e espectadores. Se a música, como já atestaram tantos estudos, opera como uma tecnologia de memória, o emprego do vídeo produziu engajamentos etnográficos e operou como meio sensível de compreensão da incorporação dessas memórias através das práticas musicais.

Erica Giesbrecht é professora visitante de Etnomusicologia na UNIRIO. É autora do livro A Memória em Negro: Sambas de Bumbo, Bailes Negros e Carnavais construindo a comunidade negra de Campinas (2011). Seu filme "Baile para matar a saudade" (2015), ganhou prêmio de melhor documentário no $7^{\circ}$ FIFER (Festival de Filme Etnográfico do Recife).

\section{REFERÊNCIAS BIBLIOGRÁFICAS}

BANKS, Marcus e MORPHY, Howard

1997 Rethinking Visual Anthropology. New Haven e Londres, Yale University Press.

BASTIDE, Roger

1951 O negro na imprensa e na literatura: a imprensa negra no Estado de São Paulo. São Paulo, USP. 
BAUMAN, Zigmund

2003 Comunidade: a busca por segurança no mundo atual. Rio de Janeiro, Jorge Zahar Ed.

BITHEL, Caroline

2006 "Musical Archaeologists: The Revival and Reconstruction of Polyphonic Settings of the Latin Mass in Corsica". Ethnomusicology Forum (online), vol. 15, issue 1: 113-145.

BOURDIEU, Pierre

2007 [1977] Esboço de uma teoria da prática. In: ORTIZ, Renato. (org). A sociologia de Pierre Bourdieu. Olho d'Água, São Paulo, p.39-72.

BUOB, Baptiste

2016 "La Caméra réflexe de l'ethnographie filmée. Se regarder regardé d'un côté, se regarder regardant de l'autre". Entrelacs. Cinéma et audiovisual.

CAIUBY NOVAES, Sylvia

2008 "Corpo, imagem e memória". In MAMMI, Lorenzo e SCHWARCZ, Lilia (orgs.). X Fotografia. São Paulo, Companhia das Letras. pp 113-131.

CLIFFORD, James e MARCUS, Ceorge

1986 The Poetics and Politics of Ethnography. California, University of California Press.

CONNERTON, Paul

1999 Como as sociedades recordam. Oeiras, Celta Editora.

CSORDAS, Thomas ].

1990 "Embodiment as a Paradigm for Anthropology". Ethos, Urbana, 18 (1): 5-47.

ERMEL, Priscilla Barra

2009 "A construção de si mesmo: uma experiência etnoaudiovisual com os povos tupi-mondé". In BARBOSA, Andréa; CUNHA, Edgar Teodoro; e HIKIJI, Rose Satiko Gitirana (orgs). Imagem-conhecimento: antropologia, cinema e outros diálogos. Campinas, Papirus. pp. 159-176.

FALCÃO, Inaicyra

2006 Corpo e ancestralidade - uma proposta pluricultural de dançaarte-educação. São Paulo, Terceira Margem. 
ARTICo| Erica Giesbrecht | Baile para matar saudades-

FELIPE, Roniel

2013 Negros heróis: histórias que não estão no gibi. Campinas.

FINNECAN, Ruth

1989 The Hidden Musicians: Music-Making in an English Town.

Cambridge, Cambridge University Press.

FOUCAULT, Michel

1990 "Tecnologias del yo". In Tecnologías del yo y otros

textos afines. Barcelona, Paidós.

GIESBRECHT, Érica

2011 A memória em negro: sambas de bumbo, bailes negros e carnavais construindo a comunidade negra de Campinas. Campinas, Pontes Editores.

GIESBRECHT, Érica e SOUZA, Carla Delgado de

2013 "Não há música sem dimensão política: conversa com Suzel Reily sobre música, etnomusicologia e os estudos acerca da cultura popular brasileira". Proa: revista de antropologia e arte, n. 4, vol. 1: doc. 7.4.1.

HALBWACHS, Maurice

1968 La mémoire collective, Paris, PUF.

HIKIJI, Rose Satiko Gitirana; CUNHA, Edgar Teodoro; e FERRAZ, Ana Lúcia

2007 "O vídeo e o encontro etnográfico". Cadernos de Campo, v. 14-15: 287-298.

2009 "Vídeo, música e antropologia compartilhada: uma experiência intersubjetiva". In: Imagem-conhecimento. Papirus. pp. 143-158.

LAPA, José Roberto do Amara

1995 A cidade: os cantos e os antros. São Paulo, EDUSP.

LAVE, Jean e WENCER Etienne

1991 Situated Learning: Legitimate Peripheral Participation.

Cambridge, Cambridge University Press. 
MACDOUGALL, David

1998 "Visual Anthropology and the Ways of Knowing". In

MACDOUCALL, David (org.). Transcultural Cinema.

Princeton, Princeton University Presss. pp. 61-91.

2006 The Corporeal Image. Princeton/Oxford, Princeton University Press.

2009 "Significado e ser". In Imagem-Conhecimento. Papirus. pp 61-70.

MACIEL, Cleber da Silva

1997 Discriminações raciais: negros em Campinas (1888-1926).

$2^{\mathrm{a}}$ ed., Campinas, Centro da Memória- UNICAMP

NOGUEIRA, Lenita. W. M.

2001 Música em Campinas nos últimos anos do Império.

Campinas, Editora da Unicamp.

REILY, Suzel Ana

2002 Voices of the Magi: Enchanted Journeys in Southeast Brazil. Chicago e Londres, The University of Chicago Press.

2006 "Remembering the Baroque Era: Historical Consciousness, Local Identity and the Holy Week Celebrations in a Former Mining Town in Brazil". Ethnomusicology Forum (online). vol. 15, issue 1: 39-62.

RICCl, Maria Lúcia Rangel

2003 "Viagem no tempo: a propósito de alguns bairros de Campinas". Notícia bibliográfica e histórica, Campinas, v. 35, n. 189: 121-135.

ROUCH, Jean

2000 Subvertendo Fronteiras. Serie Trajetórias. LISA-USP. Filme, Cor, 41 min.

SIMSON, Olga R. de Moraes

2005 Palestra musicada - apresentação com o grupo de samba Cupinzeiro, enfocando o tema Memória do Samba Paulista.

2007 Carnaval em Branco e Negro, Carnaval Popular Paulistano (19141988). Campinas. Ed. da Unicamp, EDUSP e Imprensa Oficial.

SLENNES, Robert

1999 Na senzala, uma flor: esperanças e recordações na formação da família escrava. Rio de Janeiro, Nova Fronteira. 
ARTICo| Erica Giesbrecht | Baile para matar saudades-

SHELEMAY, Kay Kaufman

2006 "Music, Memory and History". Ethnomusicology

Forum (online), vol.15, issue 1:17-37.

SMALL, Christopher

1998 Musicking: The Meanings of Performing and Listening.

Middletown, Wesleyan University Press.

SAUTCHUK, Carlos E.

2012 "Cine-Weapon: The Poiesis of Filming and Fishing".

Vibrant-Virtual Brazilian Anthropology, v. 9, n. 2.

TEIXEIRA, João Gabriel L.C., GARCIA, Marcus Vinícius C. e GUSMÃO, Rita (orgs.)

2004 Patrimônio imaterial, performance cultural e (re)

tradicionalização. Brasília: ICS-UNB.

TENÓRIO, Valquíria Pereira

2007 Baile do Carmo: um estudo sobre a construção de identidade

negra em Araraquara - SP. São Carlos, dissertação de

mestrado, Universidade Federal de São Carlos.

TURINO, Thomas

1993 Moving Away From Silence. Chicago, University of Chicago Press.

2008 Music as Social Life: The Politics of Participation.

Chicago, University of Chicago Press.

ZUMTHOR, Paul

1993 A letra e a voz. Trad. Amalio Pinheiro e Jerusa Pires

Ferreira. São Paulo, Companha das Letras. 


\section{ABSTRACT}

Among the vehement topics in contemporary ethnomusicological debates, the relations between music and memory, especially musical recreations, have provided a fertile ground for reflections. Inserted in these discussions, the present article discusses a process of musical recreation produced in a joint effort between researcher and ethnographic subjects. Namelly the "Baile para matar saudades", a dance party held in Campinas, in 2014, with the purpose of reproducing the black dances of the 1950 in the innerside of São Paulo. The images of this event, its preparation and other musical practices of my interlocutors in the present days, were used In my homonymous feature film as a way of disseminating the research. In ethnomusicology, as well as in anthropology, the question of the forms of representation and native expression presents challenges, given their ethnographical nature. The development of these subjects by visual anthropology also serves ethnographies interested in human interactions mediated by music, for reasons ranging from the extratextual possibilities of expression of dance and music to ethnographic dialogue and the representativeness of subjects in the field. The final scope of this article, therefore, is to discuss the roles of filmmaking in a research interested in the emergence of memories through musical re-creation.

\section{KEYWORDS}

Memory, Body,

Music, Dance, Black

Community, Black

Dances, Campinas

Recebido em 10 de setembro de 2016. Aceito em 27 de junho de 2017. 